\title{
除雪作業 の実際
}

\section{1. 本州の道路}

\author{
浅 井 新 一 郎
}

除雪作業の実態については, 何と云っても北海道の直 轄除雪が最も組織的であり, かつその規模も大きく, 除 雪作業の運営については我が国における指導的な立場を とっているので, 作業の詳細についてはむしろそちらの

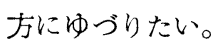

内地の除雪事業は，1級国道中の直轄管理区間のみに ついて国が施行し，それ以外はすべて県ないし市町村が 実施しているので，国が担当している除雪区間の延長は わづかに $345 \mathrm{~km}$ (昭和 35 年度) に過ぎない。これに対し て県施行の除雪区間は昭和 35 年 1 月末現在の調べでは約

表-1 府県施行の除雪延長（昭和 34 年度）

\begin{tabular}{|c|c|c|c|c|c|}
\hline & & $\begin{array}{c}\text { 除雪延長 } \\
(\mathrm{km})\end{array}$ & $\begin{array}{l}\text { 右の内指 } \\
\text { 定路線に } \\
\text { 含まれる } \\
\text { むの }\end{array}$ & $\begin{array}{c}35 \text { 年 } 1 \text { 月 } \\
\text { 末事業費 } \\
\text { (千円) }\end{array}$ & $\begin{array}{l}\text { 右の内指 } \\
\text { 定路線に } \\
\text { 含まれる } \\
\text { もの }\end{array}$ \\
\hline 青 & 森 & 347 & 347 & 9,211 & 9,211 \\
\hline 岩 & 手 & 1,949 & 847 & 10,603 & 6.720 \\
\hline 秋 & 田 & 848 & 827 & 14,500 & 14.150 \\
\hline 宮 & 城 & 582 & 327 & 2,123 & 1.083 \\
\hline 山 & 形 & 391 & 391. & 3,500 & 3.500 \\
\hline 福 & 島 & 488 & 419 & 2,379 & 2.043 \\
\hline 栃 & 木 & 117 & 60 & 500 & 265 \\
\hline 群 & 馬 & 81 & 81 & 200 & 200 \\
\hline 新 & 潟 & 581 & 521 & 6,150 & 6,100 \\
\hline 山 & 梨 & 28 & 28 & 13 & 13 \\
\hline 長 & 野 & 431 & 367 & 1,164 & 1,083 \\
\hline 富 & 山 & 1,890 & 1,690 & 806 & 726 \\
\hline 石 & $川$ & 837 & 648 & 1,841 & 1,383 \\
\hline 吱 & 阜 & 402 & 304 & 2,150 & 1,773 \\
\hline 愛 & 知 & 14 & 6 & 29 & 17 \\
\hline 福 & 井 & 942 & 624 & 10,977 & 8,116 \\
\hline 滋 & 賀 & 247 & 208 & 2,370 & 2,100 \\
\hline 京 & 都 & 542 & 439 & 1,046 & 850 \\
\hline 兵 & 庫 & 414 & 235 & 284 & 206 \\
\hline 鳥 & 取 & 592 & 392 & 959 & 599 \\
\hline 岡 & 山 & 115 & 83 & 97 & 64 \\
\hline 広 & 島 & 194 & 95 & 428 & 244 \\
\hline 合 & 計 & 13,170 & 10,034 & 96,530 & 84,696 \\
\hline
\end{tabular}

*建設省道路局企画課課長補佳 13,200km に達しており，これに対する事業費として昭 和 34 年 12 月〜昭和 35 年 1 月の 2 ケ月間に 96,600 千円が県 単独で支出されている。

内地の直轄除雪は昭和 33 年度直轄道路維持の開始と同 時に初めて実施され，当初は保有土工機俄を主力とした ものであり，未だ実施延長も短かく，その成果はむしろ 今後に期すべきであろう。一方各府県の除雪事業は雪寒 法の施行以来飛躍的な伸びを示し, 今日各府県の除雪機 㭜勢力は表一 2 に示す通り成長した。

\section{表一2 府県保有除雪機栈台数}

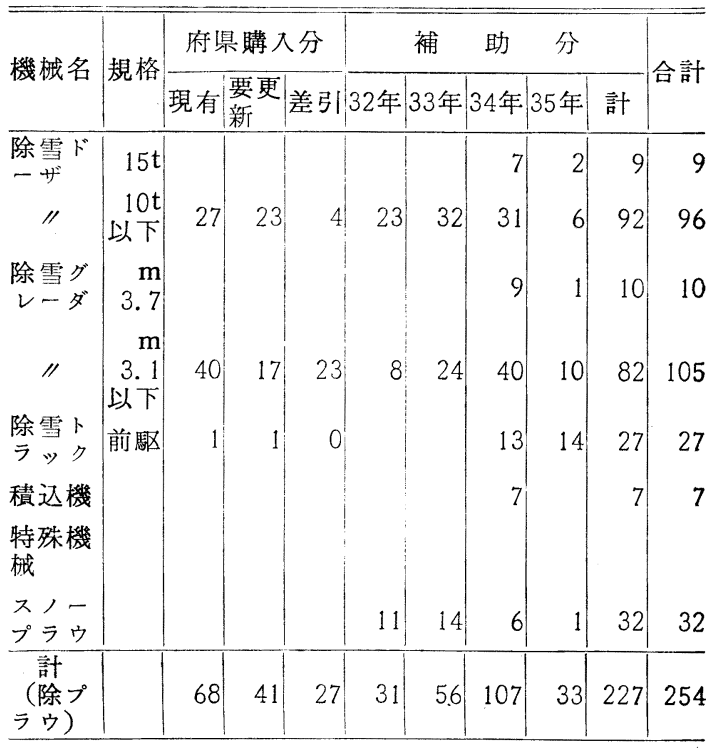

各府県における機械化除雪の方法は, 積雪量, 除雪日 数, 交通量, 保有機珹の数々種類等によりそれぞれの立 場で計画されており，その実態には可成りの開きがある ようで一律には説明しにくいが，一般に交通量と路線の 重要度に応じて次の 3 段階に分けて考えられている。

$\mathrm{A}$ 級除雪 冬期間常時 2 車線以上を磪保し, ほぼ夏季 の路面状態に保つ完全除雪

B級 II 2 車線確保を原則とするが, 夜間は大雪時 以外は除雪せず，降雪量によっては一時的 1 車線確保に切替える準完全除雪

C級 "1 1 車線確保を原則として, 待壁所を設け, 
表一3 機栰除雪標準能力 (単位 $1 \mathrm{~cm} /$ 台)

\begin{tabular}{|c|c|c|c|c|c|c|c|c|c|c|}
\hline \multirow{2}{*}{\multicolumn{2}{|c|}{ 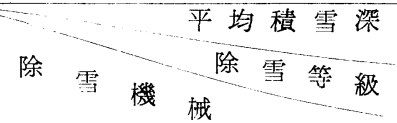 }} & \multicolumn{3}{|c|}{$50 \mathrm{~cm}$ 尔満 } & \multicolumn{3}{|c|}{$50 \sim 100 \mathrm{~cm}$} & \multicolumn{3}{|c|}{$100 \mathrm{~cm}$ 以上 } \\
\hline & & A & B & $\mathrm{C}$ & A & B & $\mathrm{C}$ & A & B & $\mathrm{C}$ \\
\hline 除彗ド 一 ザ & $10 \mathrm{t}$ 以下 & - & - & - & 14.5 & 17.5 & 24 & 11 & 13 & 18 \\
\hline IIグレーダ & 3. $1 \mathrm{~m}$ 以下 & 24 & 30 & 40 & 18 & 22 & 30 & - & - & - \\
\hline //トラック & 前 & 24 & 30 & 40 & - & - & - & - & - & - \\
\hline
\end{tabular}

表一4 内地に打ける平均除雪単価

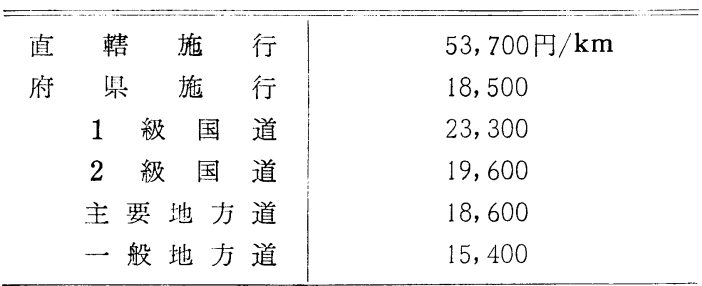

大雪，吹雪時等には一部交通不能となる様 な不完全除雪

除雪機の使用数とその組合せ浪これら除静級と積雪量
によって決められるが, およそその標準は50cm未満の積 雪に対してはトラックとグレーダー(中型), $50 \sim 100 \mathrm{~cm}$ の積雪に対してはグレーダー（中型及び大型）と中，小 型ドーザー，100cm以上の積雪に対しては大型ドーザー 及び, 中，小型ドーザーの組合せが採られている。これ ら機種別の除雪標準能力は大略表一 3 の通りである。 又各府県の除雪単価についても東北・北洼の豪雪地帯 から山陰の偭雪地方まで大きな開きがあるが，現在実施 されている内地の除雪事業の平均単価は道路種類别にお およそ表-4のようなものである。

\section{2. 北海道の道路}

\section{伊 福 部 宗 夫*}

道路除雪は鉄道の除雪と異なりそその道路の重要度に 応じた等級に区分して実施することが経済的である。又 交通量があまりに少ない場合（200台/日以下）は自然交 通輾圧の補助がないために却って除雪費の増大を見る場 合が多く, この点は乾雪の多い北海道の特色である。従 って交通量200台/日以上という原則的な線が北海道の場 合, 除雪路線の決定の重要な要素となっている。以上の ような諸点を湖案して北海道開発局では除雪区分を下記 の通りに定め作業害施上の基準要領としている。

第一種：交通量1,000台/日以上とし昼夜の別なく除雪 を実施し完全交通を確保する。

第二種：交通量500台/日内外として車線確保を原則と する。原則として夜間は行なわない。

第三種：交通量300台/日内外として 1 車線確保を原則 として所々に待避所を設ける。

実施の目標は一・種はグレーデイングを行なうが， 第三種は通行可能をもって限度とする。

この基準に従って行なう作業を大別すると(1) 除雪, (2) 拡巾, (3) 路面整正, (4) 排雪, (5) 其の他 の項目に 分けることができる。以下此の区分こ従って設明すると

* 北海道開発局土木試験所長

\section{1. 除雪}

(1) 除雪車の出動を必要とする路面除雪深は次の標準 による。

$$
\begin{array}{lcccc}
\text { 第一種 } & \text { 宣間 } & 5 \mathrm{~cm} & \text { 夜間 } & 10 \mathrm{~cm} \\
\text { 第二, 三種 } & \text { " } & 10 \mathrm{~cm} & \text { " } & 15 \mathrm{~cm}
\end{array}
$$

(2) 路面に固着せる雪の希ましい深さは次の標準とす る。

第一種および舖装道: $\quad 10 \mathrm{~cm}$ 程度

第二, 三種および砂利道：20 cm程度

\section{(3) 高速除雪}

降雪当初の時期は積雪量も少いので殆んぞ高速除雪車 の活動のみで充分であるが, 除雪が盛んとなる 1 月以降 は規準に従って出動するのであって, まづ1車線の確保 を緊急作業として次いで路巾を拡巾するよう往復作業が 行なわれる。

作業は多くは夜間および早朝の交通量の少い時期に実 施するが, 昼間も降雪の多い場合は状況に即応した作業 を行ない路面堆雪の増大を防止する。

山問部などで降雪が大となり高速車運転の困難な場合 あるい法特に第 3 種で地方により湿雪が多く高速車で吹 きとばせないような籄所はブルドーザー等の強力な低速 車を併用することもあるが, 除雪作業の主体性は高速除 